\title{
IAMJ
}

INTERNATIONAL

AYURVEDIC

MEDICAL JOURNAL

\section{UTILITY AND SIGNIFICANCE OF ANUPANA}

\section{$\underline{\text { Bhogavalli Jhansi }}^{1}$, $\underline{\text { Suguna Jyothy.P }}^{2}$, $\underline{\text { Madhusudhan Rao. }}^{3}$}

${ }^{1}$ P.G Scholar, ${ }^{2}$ Professor \& HOD, ${ }^{3}$ Associate Professor

Department of Dravyaguna, Dr. N.R.S. Govt. Ayurvedic College, Vijayawada, India

Corresponding Author: bhogavallijhansi955@gmail.com

https://doi.org/10.46607/iamj13p6012021

(Published online: November 2021)

Open Access

(C) International Ayurvedic Medical Journal, India 2021

Article Received: 19/09/2021 - Peer Reviewed: 19/11/2021 - Accepted for Publication: 20/11/2021

\section{Check for updates}

\section{ABSTRACT}

Ayurveda science of life with the aim "Swastasya Swasthya Rakshanam and Aturasya Vikara Prashamanam" has a different approach towards Arogya Sthapana. Anupana concept is one such inseparable concept of Ayurveda in the treatment aspect. Along with the main medicated drug the adjuvant with which it is taken, plays an important role in the success of treatment. Anupana (Vehicle) is a substance that is taken, along with or after the intake of Aahara (food) and Aushada (drug). In the context of food, Anupana helps in better digestion, absorption \& provides complete nourishment of the body. It brings some changes in the substance along with which it is administered. It also plays a very significant role in treating the diseases \& helps the drug to improve efficacy. On review of literature, Anupana has a multidimensional effect; it will act as a nutritive, stimulant, preventive and curative.

Keywords: Anupana, Ahara, Ayurveda, adjuvant

\section{INTRODUCTION}

Ayurveda science of life with the aim "Swastasya Swasthya Rakshanam and Aturasya Vikara Prashamanam" has a different approach towards Arogya sthapana. The concept of Anupana is mentioned in both conditions. The word Anupana is not directly available in the Vedic period. But can be traced with different aspects like Aachamana, the Paana which is taken with some of the regimens to 
cure the diseases. Vishnu purana, it is mentioned that while consuming Aahara the Jala has to be taken in between and after the food. Anupana is described along with foodstuffs as well as medications under different conditions. They are having the simplest to the obscure functions in different ways.

Nirukti of the word Anupana is derived from, Anu+ Pana. 'Anu' - Paschyat, 'Pana'- Paadhatu \& Lyut Pratyaya $^{l}$.These substances which are drunk along with or after medicine or food intake is known as "Anupana." The substance which reduces the ailment by augmenting the action of the medicine, when taken along with it is known as "Anupana."

Types: -

1. Panam: - Taken without time specifications according to one's taste.

2. Sahapanam: -which causes the fast distribution to all the dhatus.

3. Anupanam: -Taken at an appropriate time with specifications.

Definitions of Anupana as per Ayurveda Acharya: 1. Dalhana commentary on Sushruta Samhita as written as "Anupana is the liquid consumed immediately after food or along with it."2

2. Chakrapani commentary on Charaka Samhita "In the context of the administration of medicinal recipes or food, Anupana stands for the vehicle which means liquids are mixed with medicine or food". ${ }^{3}$

3. As per Vagbhatacharya "Anupana is the media which can be given either before or after or along with drug or diet."4

4. Yogratnakara "If the medicine is given by the intelligent physicians for curing particular disease along with Anupana, it will cure that specific disease definitely by the strength of Anupana." 5

5. As per Adhamalla commentary on Sarangdhara "Anupana has defined as the vehicle used after administration of the main drug."

6. Dravya Guna Vigyana Part -1 "Consumption of the medicine \& food are Anu sahapaschat (along with \& after) taken liquids known as Anupana."

Requirements of Anupana: -

Should have properties opposite to food.
Eg: - Rooksha Anupana for Snigdha Ahara, Amla Rasa Anupana for Madhura Rasa, Seetha Anupana for Ushna. Should not act as an antagonist to dhatus

Best Anupana: -

Mahendra Jala (Rainwater) is considered the best Anupana ${ }^{6}$. Vriddha Vagbhata considers Jala as best because it is the chief source of all tastes, it is satmya to all and possesses properties sustaining life $^{7}$.

Effects of Anupana ${ }^{8}$ : --

Anupana gives rise to Urja- -Manah Praharsha (pleasing mind), Tripthi- Sarira Indriya Prinana (Satisfaction to body and senses), Dridhangata-Sthira Sariratva-Stability of the body, Annasanghatashaithilyam -loosening of hard masses of food, Viklithi-Proper liquefication (moistening), Jarana -digestion

Indications of Anupana': -

Indicated in Mandakarma (less active in works), Manda Anala (less appetite), Sukumara, Sukhochitha (always treated with pleasing things), Arogyavan

\section{Contraindications of Anupana ${ }^{10}$ : -}

There are some conditions where Anupana is contraindicated. Therefore, caution should be taken in people with the following conditions like Urdhwa Jatrugatha Rogas, Swasa, Kasa, Urakshata, Pinasa, and Swarabheda.

\section{Contraindications after Anupana ${ }^{11}$ : -}

After the use of Anupana all persons should avoid following activities like Adhva (walking), Bhashya (speech), Adhyayana (learning), Geetham (singing) Swapnam (sleeping)

Anupana should be avoided in Balina, Khara Bhukshya, Deepthagni, Karmanitya. ${ }^{12}$

Dosage of Anupana ${ }^{13}$ : -

The dose of Anupana depends on Doshas

For Vata Rogas - 1 Pala (48grams)

Pitha Rogas - 2 Pala (96grams)

Kapha Rogas -3 Pala (144grams)

Anupana mentioned for Doshas: -

Vata- Sura, Souvirak, Thushodaka, Dhanyamla, Phalaml

Pitha- Mrudvika Swarasa, Amalaki Swarasa, Parushaka Swarasa

Kapha-Madhu, Gomutra, Kwatha 
The selection of Anupana is done based on Gunas opposite to the qualities of Tridosa. In Vata Janya Rogas Anupana Dravyas have opposite qualities like Snigdha, Ushna. In Pitta Janya Vikaras Dravyas having Madhura, Seetha Gunas and in Kapha Janya Vikaras Dravyas Rooksha, Ushna Gunas are to be taken.

Time of administration of Anupana ${ }^{14}$ : -

Effect of Anupana differs according to the time of taking.

$>$ Aadi -Anupana took before food - Karshanartha (for emaciation)

$>$ Madhya -Anupana took along with food Sthapanartha (for maintenance)

$>$ Anthya -Anupana took after food Brumhanartha (for nourishment)

Anupana selection criteria: -

The Anupana has to be selected based on different factors like Vyadi, Kala, Dravya and Ahara.

Generalized Anupana according to disease: -

In Vaidya Jeevan (1538-1608A.D), Anupana (Vehicle) is described according to disease. This type of Anupana is a drug itself and act synergistically when used as Anupana with the main drug.

Table 1: Different Anupanas in different diseases (Vyadhi's)

\begin{tabular}{|l|l|}
\hline Disease & Anupana \\
\hline Shula & Hingu \& Ghrita \\
\hline Purana Jwara & Madhu \& Pippali \\
\hline Prameha & Triphala \& sugar \\
\hline Vata Vyadhi & Rasona \& Ghrita \\
\hline Sannipata & Ardaka \& Madhu \\
\hline Swas & Trikatu \& Madhu \\
\hline Jwara & Nagara Motha \\
\hline Grahani & Takra \\
\hline Arshas & Chitraka Moola \\
\hline Krimi & Vidanga \\
\hline Visha & Swarna Patra \\
\hline Vamana & Laja \\
\hline Ajeerna & Ushnodaka \\
\hline Atisara & Kutaj \\
\hline
\end{tabular}

Table 2: Different Anupana according to different Kala Eg: -Haritaki

\begin{tabular}{|l|l|}
\hline Grishma & Guda \\
\hline Varsha & Lavana \\
\hline Sarat & Sita \\
\hline Hemantha & Nagara \\
\hline Sisira & Pippali \\
\hline Vasantha & Madhu \\
\hline
\end{tabular}

Table 3: Showing Single drug indicated in different diseases with different Anupanas

Dravya -Vikara-Anupana

Guduchi -

\begin{tabular}{|l|l|}
\hline Vata vikara & Ghrita \\
\hline Pitta vikara & Sita \\
\hline Kapha vikara & Madhu \\
\hline Vibanda & Guda \\
\hline Vata rakta & Eranda taila \\
\hline
\end{tabular}

\section{According to food}

> Yava, Godhuma - Cold water

> Masha-Dhanyamla, Dadhi, Masthu

$>$ Mamsa-Madya

Sneha preparations: -

> Ghritha-Ushna Jala

$>$ Thaila -Yoosha

$>$ Vasa, Majja-Manda

\section{Anupana Karmukata: -}

As the drop of oil put on the surface of stable water spreads so quickly, similarly, the Oushadha along with the Anupana spreads in a fraction of time throughout the body and produces its effect when administered with appropriate Anupana. Proper Anupana brings the refreshment of the body quickly and helps in easy digestion results in promotion of longevity, strength, pleasure, softening and liquefying of medicine, digesting, assimilation and instant diffusion of medicine.

\section{DISCUSSION}

When Anupana is administered to the healthy person it does Tarpana, Preenana, Urjakara, Bruhmana, Ayu, Jeevana, Balam, Deepana., Vrushya, Varnya etc., 
Adjuvants are nothing but assisting or aiding; A substance that aids another, such as an auxiliary remedy. A nonspecific stimulator of the immune response. For instance, Honey contains easily digestible fructose. It aids easy absorption by active transport. It augments the action of medicine by yogavahitva (easily circulated throughout the body).

When we see the Nirukti and definitions of the Anupana it seems to be a drink that is taken after the primary substances to enhance the properties of the base, protect undesired effects of the substance.

Sahapana is defined as media administered along with the basis that spreads very quickly as the Agni and brings separation of Paramanu is called Sahapana. For instance, Hingvastaka Churna in Takra.

Anupana could be different in action i.e, could be inversely proportional to the qualities of the food but never be incompatible (Viruddhata) for Dhatu.

When Anupana administrated in contraindicated patients causes Pradushti of Amasaya because of Sthana Samsraya of Dosas situated in Uras and Kanta causing Rogas which further leads to Kapha Srava, Manda Agni, Chardi

When taken before food, it is affected by the Apana Vayu becomes Ruksha, hinders the Ahara Akansha (appetite)and does the Dehakarshana (emaciation) Anupana when taken in the middle of the food, Anupana along the Sneha Guna of Pitta maintains the body equilibrium.

Anupana when taken after food, associated with Kapha, Anupana becomes Snigdhata\& nourishes the body. Hence according to the necessity, Anupana should be selected.

Dhanyamla has Ushna Veerya which mainly act as Vata Samaka. Mrdvika has Madhura Rasa, Madhura Vipaka which acts as Pitta Samaka while Madhu has Rukshaguna, Kashaya, Madhura rasa, which acts Kledamedhovisosana.

The Vata Dosha is predominantly involved in the pathogenesis of Shula Roga, Hingu because of its Ushna Veerya \& Vata-Anulomana karma alleviates the aggravated Vata Dosha and pacifies Shula.
In Sishira Ritu (winter season), the intensity of sun rays will gradually increase, along with this Ruksha Guna (dryness) also increases and the strength of a person gradually decreases due to excess coldness. The accumulation of Kapha takes place in this season. To mitigate the accumulated Kapha, Haritaki should be taken with Pippali, as it is good Sleshmahara (Kapha mitigate), due to its Katu Rasa (pungent taste), Laghu, Tikshna Guna (lightness and penetrating properties) and Ushna Virya. Apart from this it also brings the Shamana Rupi Pitta to its equilibrium state. By this, it maintains the equilibrium status of the dosha leading to Agni Samyata, Dhatusamyata (equilibrium state of Agni and body tissue) and ultimately leads to Rasayana Karma.

In Vasanta Ritu (spring season), Ahara and Oushadha Dravyas (food and medicines) are Madhyama Rukshata (moderately dry) and astringent. Hence, the strength of a person is reduced. The aggravation of Kapha takes place in this Ritu. To mitigate the aggravated Kapha, Haritaki should be taken with Honey. The Laghu, Ruksha Guna (lightness and dryness) and Kashaya Rasa (astringent taste) of Haritaki and Madhu help to mitigate Kapha. Ushna Virya of Haritaki also acts as Kaphahara. Because of its Madhura Vipaka, this combination also acts as Rasayana.

In Grishma Ritu (Summer season), Dravyas have Atirukshata Guna (excessive dryness) and Katu Rasa (pungent taste) which considerably reduce the strength of a person. Accumulation of Vata \& mitigation of Kapha will take place in this season. Ushna Guna \&Madhura Vipaka of Haritaki helps to prevent the Vata Sanchaya.Guda being Madhura Rasa, Guru, Snigdha Guna \& Madhura Vipaka pacifies Vata. By this, it checks Vata from moving into further Kriyakalas (pathological stages). Ushna Virya, Laghu \& Ruksha Gunas of Haritaki brings the Samana Rupikapha to its equilibrium state.

In Varsha Ritu (rainy season)), Dravyas have Alpa Rukshata (mild roughness), Amla rasa (sour taste). Agni (digestive power) becomes irregular. Bala (strength) of the person is less. Due to Mandagni 
(decreased digestive energy) and excess cold, Sanchaya (accumulation) of Pitta Dosha and Prakopa (aggravation) of Vata takes place. By the intake of Lavana Rasa aids in digestion causes a moistening effect.

In Sharad Ritu (autumn season) Madhyama Snigdha (mild unctuousness) and Lavana Rasa (salt taste) are predominant. Agni (digestion) becomes Teeekshna (increased), Bala (strength) of the person is Madhyam (moderate), due to predominance of Snigdha Guna, Lavana Rasa. Haritaki with Sharkara (sugar candy) does purification of provoked Pitta, due to its Snigdha Guna (unctuousness), Madhura Rasa (sweet taste) and Vipaka (post digestion). By this, the Pitta gets purified. When the Pitta Dosha is purified, it restores the strength and digestive capacity of the person. Madhura Rasa, Madhura Vipaka and Sheeta Virya of Sharkara prevent the further vitiation of the Pitta. Along with this, they help in mitigating Shamana Rupi Vata (which are under the mitigating stage), due to their Snigdha Guna, Madhura Rasa and Vipaka. The Ushna Virya of Haritaki mitigates the Vata.

In Hemanta Ritu (winter season), Snigdha Guna and Madhura Rasa are predominant. In this season the strength of the person is good, the Pitta is mitigating and Kapha is at its accumulating stage. It mitigates the Kapha at its accumulating stage and prevents aggravation, due to Ushna Virya (hot potency), Katu, Tikta, Kashaya Rasa (pungent, bitter, astringent taste), Laghu, Ruksha Guna (lightness, dryness) of Haritaki and Shunti (ginger). Along with this, it helps to bring back the Pitta to an equilibrium state by its Madhura Vipaka. Due to its Ushna Virya it stimulates the Agni which gets impaired during vitiation of Pitta.

When it comes to the application of cold water in wheat foods. There is a protein called "Gluten" common for Yava and Godhuma. Gluten is responsible for the texture of flour. Gluten becomes hardened by the application of hot water. Solubility means digestibility Even though cold water decreases the rate of digestion generally, Yava and Godhuma can be easily soluble and digestible in cold water.
The action of Coldwater in curd digestion, Curd is easily digestible than milk. It contains high fractions of lactic acid. Lactic acid formation during digestion is responsible for heartburn. Curd is culprited for heartburn in most people. While taking with cold water, reduces the risk of heartburn. Likewise, the action of Alcohol and cold water, Alcohol absorbs slowly in presence of cold water in comparison with water. Rapid absorption reduces the efficacy of the liver because detoxification takes place at the liver. Absorption of alcohol from the stomach irritates the membrane. Coldwater gives a soothing effect to the mucous membranes of the stomach. The action of Honey and cold water, like honey, contains enzymes for easy digestion and absorption. Which is more active in cold water? The action of Lukewarm water in carbohydrate digestion Enzymes for carbohydrate metabolism secrete more in hot compared with cold. So Anupana in this contest aims for easy digestion.

As the drop of oil put on the surface of stable water spreads so quickly, similarly, the Oushadha along with the Anupana spreads in a fraction of time throughout the body and produces its effect when administered with appropriate Anupana. Proper Anupana brings the refreshment of the body quickly and helps in easy digestion results in promotion of longevity, strength, pleasure, softening and liquefying of medicine, digesting, assimilation and instant diffusion of medicine. For instance, when two substances are administered simultaneously, one may alter the response of the other which may be beneficial or harmful effect Eg: -Vatsanabha with Tankana here Tankana minimizes the Vishata (toxic effects) \& prevents undesired effects.

\section{CONCLUSION}

The concept of Anupana is a unique contribution\& essential part of the administration of Ahara as well as Oushada. Anupana plays a major role regarding potentiating drug action through pharmacodynamics and pharmacokinetics as well as improvement of Aushadabala \& Rogibala. With the help of some drugs, we can treat many kinds of diseases with 
different Anupana which means Anupana can easily intervene in the mode of action of the main drug.

\section{REFERENCES}

1. Deva Raja Radhakant. Shabda Kalpa Druma. Chaukhamba Sanskrit Publications; Varanasi $2^{\text {nd }}$ Edition (2000). Vol -1, Pgno-50.

2. Acharya Priyavat Sharma. Sushruta Samhita. Chaukambha Orientalia; Varanasi $8^{\text {th }}$ Edition (2005). Sutra Stana, $46^{\text {th }}$ Chapter, Verse 419, Pgno244.

3. Acharya Agnivesha, Charaka Samhita, English Translation By R.K. Sharma \& Bhagwan Dash, Chowkhamba Krishnadas Academy, Varanasi, Reprint Edition, (2013); Vol -1 Sutrasthana 27 $7^{\text {th }}$ Chapter, Verse 319, Pg No -133.

4. Acharya Vagbhata, Astanga Hridayam, English Translation By Prof. K. R Srikanta Murty, Chowkhamba Krishnadas Academy, Varanasi, Reprint $9^{\text {th }}$ Edition (2013), Vol-1sutrasthan $8^{\text {th }}$ Chapter, Verse 50, Pg No -133.

5. Yogaratnakara, English Translations By Asha Kumara \& Premavati Tevari, Chaukhamba Visvabharati, Varanasi, $1^{\text {st }}$ Edition (2010); Part $-2,6^{\text {th }}$ Chapter, Verse -77, Pgno - 1252.

6. Sushruta. Sushruta Samhita. Edited By Acharya Priyavat Sharma. Chaukambha Orientalia Publication Varanasi; $8^{\text {th }}$ Edition (2005). Sutra Stana, $46^{\text {th }}$ Chapter, Verse 434, Pgno-245.

7. Vriddha Vagbhata. Astanga Samgraha. Edited By Kaviraja Jyotirmitra Acharyas. Edited By Dr. Shivaprasad Sharma. Chowkhambha Press; Varanasi; Reprint. $1^{\text {st }}$ Edition (2006); Sutrasthana, $10^{\text {th }}$ Chapter, Verse 31, Pgno - 105.

8. Mishra Umapathi, Dravya Guna Sangraha Of Chakrapani Datta. Chowkhamba Surabharathi Prakashana, Varanasi; Reprint Edition (1995); Verses: - 86,90,161,163.

9. Acharya Vagbhata, Astanga Hrudayam, English Translation By Prof. K. R Srikanta Murthy, Chowkhamba Krishnadas Academy, Varanasi; Reprint $9^{\text {th }}$ Edition (2013); Vol-1 Sutrastha Stana $8^{\text {th }}$ Chapter, Verse -52, Pg No-133.

10. Susrutha. Susrutha Samhita. Edited By G.D. Singhal; Chaukhambha Sanskrit Pratishthan, Delhi; Reprinted (2015), Vol-1 Sutrasthana $46^{\text {th }}$ Chapter, Verse -443 , Pgno -482.

11. Vriddha Vagbhata. Astanga Samgraha. Edited By Kaviraja Jyotirmitra Acharya. Edited By Dr
Shivaprasad Sharma. Chowkhambha Press; Varanasi: Reprint $1^{\text {st }}$ (2006). Sutrasthana, $10^{\text {th }}$ Chapter, Verse 35. Pg No - 106.

12. Susrutha. Susrutha Samhita, Edited By G.D. Singhal, Chaukhambha Sanskrit Pratishthan; Delhi Reprinted (2015), Vol -1 Sutrasthana $46^{\text {th }}$ Chapter, Verse -443 , Pg No -482 .

13. Acharya Sharangdhara, Sharangdharasamhita, English Translation By Prof.K.R. Srikantha Murthy, Chaumkhamba Orientalia, Varanasi, Reprint Edition (2012); Madhyamkhanda, $6^{\text {th }}$ Chapter, Verse $-05, \mathrm{Pg}$ No -85.

14. Acharya Sharangdhara, Sharangdharasamhita, Edited By Srikantha Murthy, Chaumkhamba Orientalia Publication, Varanasi; Reprint Edition (2016); Madhyama Khanda, $6^{\text {th }}$ Chapter, Verse, -04: Pgno:85.

\section{Source of Support: Nil \\ Conflict of Interest: None Declared}

How to cite this URL: Bhogavalli Jhansi et al: Utility And Significance Of Anupana. International Ayurvedic Medical Journal \{online\} 2021 \{cited November 2021\} Available from: http://www.iamj.in/posts/images/upload/3240_3245.pdf 